\title{
Synthesis and Antifungal Evaluation of Quaternary Ammonium Salts Derivatives of Dialkylaminoethyl Methacrylate Bearing 1,3,4-Oxadiazoles Moieties
}

\author{
Zahra OULD KADA ${ }^{\mathrm{a}}$, Tahar BENAISSA ${ }^{\mathrm{b}}$, Nisserine HAMINI-KADAR ${ }^{\mathrm{c}}$ \\ and Sofiane DAOUDI ${ }^{\text {b* }}$ \\ ${ }^{a}$ Department of Chemistry, University Djillali Liabes of Sidi Bel Abbes 22000, Algeria. \\ ${ }^{b}$ Chemical Physics Laboratory, University of Moulay Tahar, Saida, 20000 Algeria. \\ 'Laboratory of Applied Microbiology, Department of Biology, Faculty of Nature Sciences and Life, \\ University of Ahmed Ben Bella 1.BP 16. Es-Senia. 31100, Oran, Algeria. \\ *Email: daoudi_20@yahoo.fr
}

Keywords: fatty acids, quaternary ammonium salts, 1,3,4-Oxadiazoles, antifungal activity.

\begin{abstract}
Starting from lauric acid two novel quaternary ammonium salts containing 1,3,4Oxadiazoles nucleus derivative from N,N-Diethylaminoethyl Methacrylate (DEAEMA) and N,NDimethylaminoethyl Methacrylate (DMAEMA) was successfully synthesized and characterized by $\mathrm{IR},{ }^{1} \mathrm{H}$ and ${ }^{13} \mathrm{C}$ NMR, All the synthesized compounds were evaluated for their preliminary in vitro antifungal activity against three fungal strains such as Fusarium oxysporum, Fusarium commune and Fusarium rodelens. The synthesized compounds showed promising antifungal potential against the phytopathogenic test fungi.
\end{abstract}

\section{Introduction}

The phytopathogenic fungal pose serious problems worldwide in the cultivation of economically important plants because induction of wilt disease in a wide range of host plants such as, for example, cereals, tomatoes, potatoes, bananas and watermelons [1-5]. The search for new antifungal agents will consequently always remain as an important and challenging task for organic chemists; natural products are often used as starting points in the drug discovery for a variety of purposes [6]. In recent years, Fatty acids have attracted much attention due to their wide range of their biological activities [7-8]. Lauric acid or dodecanoic acid (C12) is a saturated fatty acid has antimicrobial activity [9] and antifungal properties against plant pathogenic fungi [10]. 1,3,4-oxadiazoles is a versatile heterocyclic nucleus have exhibited a wide range of biological properties [11], such as anti-bacterial [12], anti-viral [13], anti-fungal [14], anti-cancer [15-16], anti-tumor [17], antiinflammatory [18], anti-hypertensive [19], anti-convulsant [20] and anti-diabetic properties [21]. Compounds containing 1,3,4-oxadiazole is an important moiety for development of new drugs [2224]. Quaternary ammonium salts (QAS) have multiple applications in industry [25], in clinical medicine [26] and in the household [27]. These compounds are used as disinfectants [28], surfactants [29] and wood preservatives [30]. The mechanism of the biocidal action of QAS compounds is based on the adsorption of positively charged alkyl ammonium salt moiety on the negatively charged cell wall and its penetration by alkyl chain which leads to a leak of low molecular components of cell [31]. In a consequence the microorganism cell dies. Literature revealed that QAS compounds containing long chain n-alkyl act good Antimicrobial [32-33] and fungicidal properties [34]. In continuation to extend our research on fungicidal compounds, we focused our attention on the synthesis of novel 1,3,4-oxadiazoles containing quaternary ammonium moiety derivatives from lauric acid and investigated their antifungal activity against three phytopathogenic fungal. 


\section{Experimental}

\section{Material and method}

All solvents and reagents used in this study were obtained from Sigma Aldrich and BIOCHEM. The purity of the compounds was routinely checked by thin layer chromatography (TLC) using silica gel F254 supplied by MERCK, using mixture of different polar and nonpolar solvents in varying proportions and spots were observed using iodine as visualizing agent. All Melting points were determined in open capillary tubes on a BÜCHI 540 melting point apparatus and are uncorrected. The Infrared spectra of reactants and product in the range of 4000-400 cm-1 were recorded as potassium bromide discs on a Shimadzu FTIR-8300 Fourier Transform infrared spectrophotometer. The ${ }^{1} \mathrm{H}$ and ${ }^{13} \mathrm{C}$ NMR Spectra were measured in Chloroform-d $\left(\mathrm{CDCl}_{3}\right)$ on Bruker AM 300 MHZ Spectrometer (University of Oran, Essenia), relative to the internal standard tetramethylsilane (TMS), and chemical shift values are expressed in parts per million $(\delta, \mathrm{ppm})$.

\section{Preparation of ethyl laurate (2)}

This ester was prepared following the standard procedure reported in the literature [36]. Lauric acid $(5 \mathrm{~g}, 0.025 \mathrm{~mol})$ was dissolved in excess of ethanol $(200 \mathrm{~mL})$ with $5 \mathrm{~mL}$ of concentrated sulfuric acid and the mixture was refluxed at $80^{\circ} \mathrm{C}$ in an oil bath for $5-6 \mathrm{~h}$, the progress of the reaction was monitored by TLC. The excess of acid was neutralized with sodium bicarbonate then the solvent was evaporated and the product was collected.

IR (KBr, v, cm-1): 1743.5 (C=O), 1170.7 (C-O-C).

\section{Preparation of lauric acid hydrazide (3)}

To a solution of lauric methyl ester $2(3.5 \mathrm{~g}, 0.016 \mathrm{~mol})$ in ethanol $(100 \mathrm{~mL})$, hydrazine hydrate $(98 \% ; 5 \mathrm{ml})$ was added and heated for $5 \mathrm{~h}$ on oil bath. The progress of the reaction was monitored by TLC, the reaction mixture was cooled, and the excess of ethanol was distilled off under reduced pressure. The crude product was filtered, washed with water and evaporated to dryness to give the products.

IR (KBr, v, cm-1): $3315.4\left(\mathrm{NHNH}_{2}\right), 1631.7(\mathrm{C}=\mathrm{O})$.

${ }^{1} \mathrm{H}-\mathrm{NMR}\left(300 \mathrm{MHz}, \delta, \mathrm{CDCl}_{3}-\mathrm{d} 6\right) \delta(\mathrm{ppm}): 7.281\left(3 \mathrm{H}, \mathrm{O}=\mathrm{C}-\mathrm{NH}-\mathrm{NH}_{2}\right), 2.326\left(2 \mathrm{H}, \mathrm{CH}_{2}-\mathrm{C}=\mathrm{O}\right)$, $0.879\left(3 \mathrm{H}, \mathrm{CH}_{3}-\mathrm{CH}_{2}-\right) .{ }^{13} \mathrm{C}-\mathrm{NMR}\left(300 \mathrm{MHz}, \delta, \mathrm{CDCl}_{3}-\mathrm{d} 6\right) \delta(\mathrm{ppm}): 174.913\left(\mathrm{O}=\underline{\mathrm{C}}-\mathrm{NH}^{-\mathrm{NH}_{2}}\right)$, $34.294\left(\underline{\mathrm{CH}}_{2}-\mathrm{C}=\mathrm{O}\right), 14.628\left(\mathrm{CH}_{3}-\mathrm{CH}_{2}-\right)$.

\section{Synthesis of 2-(bromomethyl)-5-undecyl-1,3,4-oxadiazole (4)}

A mixture of hydrazide 3 (2g, 0.0094mol), bromoacetic acid $(1.31 \mathrm{~g}, 0.0094 \mathrm{~mol})$ and phosphoryl chloride $(5 \mathrm{ml})$ was refluxed on a oil-bath for $6-8 \mathrm{~h}$. The progress of the reaction was monitored by TLC. After cooling to room temperature, the resulting precipitate was filtered, washed with water and dried.

IR (KBr, v, cm-1): $1598.9(\mathrm{C}=\mathrm{N}), 1002.9$ (C-O-C), 495.7 (C-Br).

${ }^{1} \mathrm{H}-\mathrm{NMR}\left(300 \mathrm{MHz}, \delta, \mathrm{CDCl}_{3}-\mathrm{d} 6\right) \delta(\mathrm{ppm}): 0.899\left(3 \mathrm{H}, \mathrm{CH}_{3}-\mathrm{CH}_{2}-\right), 2.320\left(2 \mathrm{H}, \mathrm{CH}_{2}-\mathrm{C}=\mathrm{N}\right), 3.684$ $\left(2 \mathrm{H}, \mathrm{N}=\mathrm{C}-\mathrm{CH}_{2}-\mathrm{Br}\right) .{ }^{13} \mathrm{C}-\mathrm{NMR}\left(300 \mathrm{MHz}, \delta, \mathrm{CDCl}_{3}-\mathrm{d} 6\right) \delta(\mathrm{ppm}): 179.126\left(-\mathrm{CH}_{2}-\mathrm{C}=\mathrm{N}\right), 154.257$ $\left(\mathrm{N}=\underline{\mathrm{C}}-\mathrm{CH}_{2}-\mathrm{Br}\right), 29.043\left(-\underline{\mathrm{C}} \mathrm{H}_{2}-\mathrm{C}=\mathrm{N}\right), 15.902\left(\mathrm{~N}=\mathrm{C}-\underline{\mathrm{CH}_{2}}-\mathrm{Br}\right), 14.083\left(\underline{\mathrm{CH}}_{3}-\mathrm{CH}_{2}-\right)$.

\section{Synthesis of 2-(bromomethyl)-5-undecyl-1,3,4-oxadiazole-DEAEMA (5a)}

An equimolar quantity of DEAEMA $(0.29 \mathrm{~g}, 0.0015 \mathrm{~mol})$ and 2-(bromomethyl)-5-undecyl-1,3,4oxadiazole (4) $(0.5 \mathrm{~g}, 0.0015 \mathrm{~mol})$ in dry acetone $(50 \mathrm{ml})$ and a small amount of hydroquinone was added, This Mixture was gently refluxed for 8 hours. TLC analysis was used to monitor the progress of the reaction. After that, the white solid that appeared on cooling was filtered and the excess solvent was removed by vacuum evaporation. The residue was washed several times with cold diethyl ether and allowed to dry.

IR (KBr, v, cm-1): $1724.2(\mathrm{C}=\mathrm{O}), 1596.9(\mathrm{C}=\mathrm{N}), 1461.9(\mathrm{C}=\mathrm{C}), 1018.3(\mathrm{C}-\mathrm{O}-\mathrm{C})$. 
${ }^{1} \mathrm{H}-\mathrm{NMR}\left(300 \mathrm{MHz}, \delta, \mathrm{CDCl}_{3}-\mathrm{d} 6\right) \delta(\mathrm{ppm}): 6.128-5.643\left(2 \mathrm{H}, \mathrm{O}=\mathrm{C}-\left(\mathrm{CH}_{3}\right) \mathrm{C}=\mathrm{CH}_{2}\right), 4.585\left(2 \mathrm{H},{ }^{+} \mathrm{N}-\right.$ $\left.\mathrm{CH}_{2}-\underline{\mathrm{C}}_{2} \mathrm{O}\right), 4.203\left(2 \mathrm{H}, \mathrm{N}=\mathrm{C}-\mathrm{CH}_{2}-\mathrm{N}+\right), 3.617\left(2 \mathrm{H},{ }^{+} \mathrm{N}-\mathrm{C}_{2}-\mathrm{CH}_{2} \mathrm{O}\right), 3.129\left(2 \mathrm{H},{ }^{+} \mathrm{N}-\mathrm{C}_{2}-\mathrm{CH}_{3}\right)$, $2.265\left(2 \mathrm{H}, \mathrm{C}_{2}-\mathrm{C}=\mathrm{N}\right), 1.940\left(3 \mathrm{H}, \mathrm{O}=\mathrm{C}-\left(\mathrm{CH}_{3}\right) \mathrm{C}=\mathrm{CH}_{2}\right), 1.326\left(3 \mathrm{H},{ }^{+} \mathrm{N}-\mathrm{CH}_{2}-\mathrm{C}_{3}\right), 0.868\left(3 \mathrm{H}, \mathrm{C}_{3}-\right.$ $\left.\mathrm{CH}_{2}-\right) .{ }^{13} \mathrm{C}-\mathrm{NMR} \quad\left(300 \mathrm{MHz}, \delta, \mathrm{CDCl}_{3}-\mathrm{d} 6\right) \delta(\mathrm{ppm}): 174.874 \quad\left(-\mathrm{CH}_{2}-\underline{\mathrm{C}}=\mathrm{N}\right), 166.443 \quad(\mathrm{O}=\underline{\mathrm{C}}-$ $\left.\left(\mathrm{CH}_{3}\right) \mathrm{C}=\mathrm{CH}_{2}\right), \quad 150.016 \quad\left(-\mathrm{N}=\underline{\mathrm{C}}-\mathrm{CH}_{2}-\mathrm{N}^{+}\right), \quad 135.491 \quad\left(\mathrm{O}=\mathrm{C}-\left(\mathrm{CH}_{3}\right) \underline{\mathrm{C}}=\mathrm{CH}_{2}\right), \quad 127.051 \quad(\mathrm{O}=\mathrm{C}-$ $\left.\left(\mathrm{CH}_{3}\right) \mathrm{C}=\underline{\mathrm{CH}}_{2}\right), 59.059\left({ }^{+} \mathrm{N}-\underline{\mathrm{CH}}_{2}-\mathrm{CH}_{2} \mathrm{O}\right), 58.113\left({ }^{+} \mathrm{N}-\mathrm{CH}_{2}-\underline{\mathrm{CH}}_{2} \mathrm{O}\right), 51.562\left(\mathrm{~N}=\mathrm{C}-\underline{\mathrm{CH}}_{2}-\mathrm{N}^{+}\right), 49.665$ $\left({ }^{+} \mathrm{N}-\underline{C}_{2}-\mathrm{CH}_{3}\right), 29.474\left(\underline{\mathrm{CH}}_{2}-\mathrm{C}=\mathrm{N}\right), 18.210\left(\mathrm{O}=\mathrm{C}-\left(\underline{\mathrm{CH}}_{3}\right) \mathrm{C}=\mathrm{CH}_{2}\right), 14.063\left(\underline{\mathrm{CH}}_{3}-\underline{\mathrm{CH}}_{2}-\right), 8.858\left({ }^{+} \mathrm{N}-\right.$ $\left.\mathrm{CH}_{2}-\mathrm{CH}_{3}\right)$.

\section{Synthesis of 2-(bromomethyl)-5-undecyl-1,3,4-oxadiazole-DMAEMA (5b)}

An equimolar quantity of compound (4) and the tertiary amine DMAEMA (0.24g, 0.0015mol) acid were dissolved in dry acetone $(50 \mathrm{ml})$ with a small amount of hydroquinone. This mixture was refluxed for 8 hours. The reaction was monitored by TLC. After that, solvent was evaporated and the products collected by filtration, washed with cold diethyl ether and allowed to dry.

IR (KBr, v, cm-1): $1722.3(\mathrm{C}=\mathrm{O}), 1687.7(\mathrm{C}=\mathrm{N}), 1467.7(\mathrm{C}=\mathrm{C}), 1161.1(\mathrm{C}-\mathrm{O}-\mathrm{C})$.

${ }^{1} \mathrm{H}-\mathrm{NMR}\left(300 \mathrm{MHz}, \delta, \mathrm{CDCl}_{3}-\mathrm{d} 6\right) \delta(\mathrm{ppm}): 6.151-5.913\left(2 \mathrm{H}, \mathrm{O}=\mathrm{C}-\left(\mathrm{CH}_{3}\right) \mathrm{C}=\mathrm{CH}_{2}\right), 4.572\left(2 \mathrm{H},{ }^{+} \mathrm{N}-\right.$ $\left.\mathrm{CH}_{2}-\underline{\mathrm{C}}_{2}\right), 4.117\left(2 \mathrm{H}, \mathrm{N}=\mathrm{C}-\mathrm{CH}_{2}-\mathrm{N}^{+}\right), 3.627\left(2 \mathrm{H},{ }^{+} \mathrm{N}-\mathrm{CH}_{2}-\mathrm{CH}_{2}\right), 3.469\left(3 \% \mathrm{H},{ }^{+} \mathrm{N}-\mathrm{CH}_{3}\right), 2.871(2 \mathrm{H}$, $\left.\mathrm{CH}_{2}-\mathrm{C}=\mathrm{N}\right), 1.905\left(3 \mathrm{H}, \mathrm{O}=\mathrm{C}-\left(\mathrm{CH}_{3}\right) \mathrm{C}=\mathrm{CH}_{2}\right), 0.816\left(3 \mathrm{H}, \underline{\mathrm{C}}_{3}-\mathrm{CH}_{2}-\right) .{ }^{13} \mathrm{C}-\mathrm{NMR}\left(300 \mathrm{MHz}, \delta, \mathrm{CDCl}_{3}-\right.$ d6) $\delta(\mathrm{ppm}): 173.492\left(-\mathrm{CH}_{2}-\underline{\mathrm{C}}=\mathrm{N}\right), 167.916\left(\mathrm{O}=\underline{\mathrm{C}}-\left(\mathrm{CH}_{3}\right) \mathrm{C}=\mathrm{CH}_{2}\right), 150.068\left(-\mathrm{N}=\underline{\mathrm{C}}-\mathrm{CH}_{2}-\mathrm{N}^{+}\right)$, $135.083\left(\mathrm{O}=\mathrm{C}-\left(\mathrm{CH}_{3}\right) \underline{\mathrm{C}}=\mathrm{CH}_{2}\right), 127.143\left(\mathrm{O}=\mathrm{C}-\left(\mathrm{CH}_{3}\right) \mathrm{C}=\underline{\mathrm{C}} \mathrm{H}_{2}\right), 59.180\left({ }^{+} \mathrm{N}-\mathrm{CH}_{2}-\mathrm{CH}_{2}\right), 58.233(\mathrm{~N}=\mathrm{C}-$ $\left.\underline{\mathrm{CH}}_{2}-\mathrm{N}^{+}\right), \quad 52.612 \quad\left({ }^{+} \mathrm{N}-\mathrm{CH}_{2}-\underline{\mathrm{CH}}_{2}\right), \quad 43.700 \quad\left({ }^{+} \mathrm{N}-\underline{\mathrm{CH}}_{3}\right), 29.604 \quad\left(\underline{\mathrm{CH}}_{2}-\mathrm{C}=\mathrm{N}\right), \quad 18.848 \quad(\mathrm{O}=\mathrm{C}-$ $\left.\left(\underline{\mathrm{CH}_{3}}\right) \mathrm{C}=\mathrm{CH}_{2}\right), 14.151\left(\underline{\mathrm{CH}}_{3}-\mathrm{CH}_{2}-\right)$.

\section{Results and Discussion}

The synthetic route designed for the compounds $\mathbf{5 a}$ and $\mathbf{5 b}$ is summarized in Scheme 1.<smiles>[R][N+]([R])(CCOC(=O)C(=C)C)Cc1nnc([CH])o1</smiles>

Scheme 1. Synthetic route to title compounds $\mathbf{5 a}$ and $\mathbf{5 b}$.

Reagents and conditions: (i) $\mathrm{C}_{2} \mathrm{H}_{5} \mathrm{OH}$, and conc. $\mathrm{H}_{2} \mathrm{SO}_{4}$, reflux for 8h; (ii) $\mathrm{NH}_{2} \mathrm{NH}_{2}-\mathrm{H}_{2} \mathrm{O}$ and $\mathrm{C}_{2} \mathrm{H}_{5} \mathrm{OH}$, reflux for $5 \mathrm{~h}$; ( iii) $\mathrm{POCl}_{3}$ and $\mathrm{BrCH}_{2} \mathrm{COOH}$, Reflux (iv) DMAEMA, DEAEMA and acetone.

Lauric ethyl ester $\mathbf{2}$ was synthesized using starting lauric acid $\mathbf{1}$ in ethanol and concentrated sulfuric acid. In the second step, the esters then converted to acid hydrazides $\mathbf{3}$ using Hydrazine hydrate in ethanol. This hydrazide was converted to give 2-(bromomethyl)-5-undecyl-1,3,4-oxadiazole 4 by ring-closing reactions using bromoacetic acid in the presence of phosphorus oxychloride. In the last step, compound 5a-b was prepared by quaternization of the corresponding tertiary amine (DEAEMA, DMAEMA) with compound $\mathbf{4}$ to give the final products. 
Table 1. Physical properties and analytical data of the synthesized compounds.

\begin{tabular}{cccccc}
\hline Compound & Color & \%Yield & Melting Point $\left({ }^{\circ} \mathbf{C}\right)$ & Rf Value & Solvent system \\
\hline $\mathbf{2}$ & Colorless & 84 & liquid & 0.33 & $\mathrm{CHCl}_{3}: \mathrm{MeOH} 1.5: 1$ \\
$\mathbf{3}$ & White & 88 & $145-147$ & 0.42 & $\mathrm{CHCl}_{3}: \mathrm{MeOH} 1.5: 1$ \\
$\mathbf{4}$ & White & 92 & $194-195$ & 0.35 & $\mathrm{CHCl}_{3}: \mathrm{MeOH} 1.5: 1$ \\
$\mathbf{5 a}$ & light yellow & 87 & semi-solide & 0.38 & $\mathrm{CHCl}_{3}: \mathrm{MeOH} 9: 1$ \\
$\mathbf{5 b}$ & light yellow & 90 & semi-solide & 0.46 & $\mathrm{CHCl}_{3}: \mathrm{MeOH} \mathrm{9:1}$ \\
\hline
\end{tabular}

\subsection{Antifungal activity}

The antifungal activities of the synthesized compounds were evaluated against three phytopathogenic fungi of tomato such as, Fusarium oxysporum, Fusarium commune and Fusarium rodelens, supplied from the fungal collection of the laboratory of Applied Microbiology Faculty of Nature Sciences and Life, Oran University, Algeria, by agar diffusion plate method [35]. In vitro Screening of Antifungal Activity of synthesized compounds was determined on the potato dextrose agar (PDA) as the growth medium for the tested fungi, and PDA was prepared by dissolving potato extract $(200 \mathrm{~g})$, D-glucose $(20 \mathrm{~g})$ and agar $(15 \mathrm{~g})$ in distilled water (1000 $\mathrm{ml}$ ). Finally, the medium was transferred to a flask, sealed, sterilized by autoclaving at $121 \mathrm{C}$ for 30 min and cooled down. The compounds were tested at various concentrations of 50,100,150 and $200 \mu \mathrm{g} / \mathrm{Ml}$ and have been incorporated into the PDA culture medium maintained molten at a temperature of 40 to $45^{\circ} \mathrm{C}$. After the mixture flow and solidification; Mycelial implants of $6 \mathrm{~mm}$ diameter on the pathogen fungi are deposited in the center of the Petri dish containing PDA medium with 04 concentrations for each synthesized compounds to be studied. The Petri-dishes were incubated at $25^{\circ} \mathrm{C}$ for 4 days. Three replications were performed. After the completion of incubation period, the Relative inhibition rate of the circle mycelium compared to blank assay was calculated via the following equation:

$$
\text { Relative inhibition rate }(\%)=[(\mathrm{T}-\mathrm{C}) / \mathrm{T}] \times 100 \%
$$

Where $\mathrm{T}$ is the extended diameter of the circle mycelium during the blank assay; and $\mathrm{C}$ is the extended diameter of the circle mycelium during testing. The antifungal activity data are listed in Table 2.

Table 2. Antifungal activity for 4 days of the synthesized compounds

\begin{tabular}{|c|c|c|c|c|c|c|c|c|c|c|c|c|}
\hline \multirow{4}{*}{ compounds } & \multicolumn{12}{|c|}{ Inhibition Zone \% } \\
\hline & \multirow{2}{*}{\multicolumn{4}{|c|}{ Fusarium oxysporum }} & \multirow{2}{*}{\multicolumn{4}{|c|}{$\begin{array}{l}\text { Fusarium commune } \\
\text { concentration in ug } / \mathrm{mL}\end{array}$}} & \multicolumn{4}{|c|}{ Fusarium rodelens } \\
\hline & & & & & & & & & & & & \\
\hline & 50 & 100 & 150 & 200 & 50 & 100 & 150 & 200 & 50 & 100 & 150 & 200 \\
\hline 3 & + & ++ & +++ & +++ & ++ & +++ & +++ & +++ & + & + & ++ & +++ \\
\hline 4 & + & + & ++ & ++ & ++ & ++ & ++ & +++ & + & + & + & +++ \\
\hline $5 \mathbf{a}$ & ++ & +++ & +++ & +++ & +++ & +++ & +++ & +++ & + & ++ & ++ & +++ \\
\hline $5 \mathbf{b}$ & ++ & ++ & +++ & +++ & +++ & +++ & +++ & +++ & + & + & +++ & +++ \\
\hline
\end{tabular}

Zone diameter of growth inhibition: $(+)<10 \mathrm{~mm},(++) 10-15 \mathrm{~mm},(+++)>16 \mathrm{~mm}$

The evaluation of antifungal activity revealed that all the synthesized compounds have a significant biological activity, the best activity was observed at a concentration of $200 \mu \mathrm{g} / \mathrm{mL}$ against all the tested fungi, and moderate activity was observed at a concentration of $150 \mu \mathrm{g} / \mathrm{mL}$. The compounds (3) and (4) displayed poor activities against Fusarium oxysporum and Fusarium rodelens at a concentration of 50 to $100 \mu \mathrm{g} / \mathrm{mL}$.

\section{Conclusion}

New quaternary ammonium compounds containing in their structure 1,3,4-oxadiazole ring system were successfully synthesized and characterized by IR, ${ }^{1} \mathrm{H}$ and ${ }^{13} \mathrm{C}$ NMR. The in vitro antifungal activity assay indicated that most of the compounds showed good to moderate antifungal activities against both systemic pathogenic fungi. These compounds can be considered as lead molecules for future investigations. 


\section{Acknowledgements}

The authors are thankful to Dr. N. HAMINI-KADAR of Applied Microbiology Laboratory, University of Esénia, Oran, for providing the antifungal activities studies. The authors are also thankful to the Head, Applied Organic Synthesis Laboratory, University of Esénia, Oran, for recording the NMR spectra.

\section{References:}

[1]. P. Benjaphorn, K. Chutima, M. Skorn, Antifungal Potential of Extracellular Metabolites Produced by Streptomyces hygroscopicus against Phytopathogenic Fungi, Int J Biol Sci. 4:5 (2008) 330-337.

[2]. D. Ralph, A.L.V.K Jan, A.P. Zacharias, E.H.K. Kim, D.P. Antonio, D. S. Pietro, J.R. Jason, D. Marty, K. Regine, E. Jeff, D.F. Gary, The Top 10 fungal pathogens in molecular plant pathology, Mol Plant Pathol. 13:4 (2012) 414-430.

[3]. D.N. Enyiukwu, A.N. Awurum, J.A. Nwaneri, Efficacy of plant-derived pesticides in the control of myco-induced postharvest rots of tubers and agricultural products: A review, Net Journal of Agricultural Science. 2:1 (2014) 30-46.

[4]. M. Wang, Q. Zhang, Q. Ren, X. Kong, L. Wang, H. Wang, J. Xu, Y. Guo, Isolation and characterization of sesquiterpenes from Celastrus orbiculatus and their antifungal activities against phytopathogenic fungi, J Agric Food Chem. 62:45 (2014) 10945-10953.

[5]. P. Tünde, J.H. Imre, P. István, Secondary metabolites in fungus-plant interactions, Frontiers in Plant Science. 6 (2015) 573.

[6]. L. Mouhssen, The Success of Natural Products in Drug Discovery, Pharmacology \& Pharmacy. 4 (2013) 17-31.

[7]. B. Ghazala, B. Naila, S. Mustafa, Pak, Fatty acids and biological activities of crude extracts of freshwater algae from sindh, Pak J Bot. 42:2 (2010) 1201-1212.

[8]. I. Hacibekiroğlu, K.Y. Pelin, H. Nesrin, K. Ersin, V. Teysel, K Ufuk, In vitro biological activities and fatty acid profiles of Pistacia terebinthus fruits and Pistacia khinjuk seeds, Natural Product Research: Formerly Natural Product Letters. 29:5 (2015) 444-446.

[9]. S. Eraricar, I.M. Ida, A.P. Qadly, Spectrum Activity and Lauric Acid Release Behaviour of Antimicrobial Starch-Based Film, Procedia Chemistry. 9 (2014) 11-22 .

[10]. D.R. Walters, R.L. Walker, K.C. Walker, Lauric Acid Exhibits Antifungal Activity Against Plant Pathogenic Fungi, J Phytopathology. 151 (2003) 228-230.

[11]. S. Kavitha, S. Gnanavel, K. Kannan, Biological aspects of 1,3,4-oxadiazole derivatives, Asian J Pharm Clin Res. 7:4 (2014) 11-20.

[12]. R.B. Mudasir, H.M. Rayees, R. Abdul, Synthesis, char acterization and anti-bacterial activity of 5-(alkenyl)-2-amino- and 2-(alkenyl)-5-phenyl-1,3,4-oxadiazoles, J Chem Sci. 122:2 (2010) 177-182.

[13]. W.A. El-Sayed, F. A. El-Essawy, M. A. Omar, S.N. Barsis, M. A. Mohamed, A.-H. A-R. Adel, Anti-HIV Activity of New Substituted 1,3,4-Oxadiazole Derivatives and their Acyclic Nucleoside Analogues, Z.Naturforsch. 64 (2009) 773-778.

[14]. X. Weiming, H. Jiang, H. Ming, H. Feifei, C. Xuehai, P. Zhaoxi, W. Jian, T Maoguo, Synthesis and Antifungal Activity of Novel Sulfone Derivatives Containing 1,3,4-Oxadiazole Moieties, Molecules. 16 (2011) 9129-9141.

[15]. A.N.Y. Megally, M.M. Kamel, Synthesis and anticancer evaluation of 1,3,4-oxadiazoles, 1,3,4-thiadiazoles, 1,2,4-triazoles and Mannich bases, Chem Pharm Bull. $63: 5$ (2015) 369-76.

[16]. Salahuddin, M. Avijit, S. Mohammad, Synthesis, Characterization, and In Vitro Anticancer Evaluation of Novel 2,5-Disubstituted 1,3,4-Oxadiazole Analogue, BioMed Research International. 2044 (2014).

[17]. K. Zhang, P. Wang, L.N. Xuan, X.Y. Fu, F. Jing, S. Li, Y.M. Liu, B.Q. Chen, Synthesis and antitumor activities of novel hybrid molecules containing 1,3,4-oxadiazole and 1,3,4thiadiazole bearing Schiff base moiety, Bioorg Med Chem. Lett. 24:22 (2014) 5154-5160. 
[18]. P.D. Ullas, B.C. Revanasiddappa, E.V.S. Subrahmanyam, Analgesic and anti inflammatory activity of 1, 3, 4- oxadiazoles derivaties, IJPCBS. 2:3 (2012) 202-205.

[19]. C. Corina, V. Şunel, H. Mihaela, J. Desbrières, M. Popa, L. Cătălina, Enhanced antipyretic activity of new 2,5-substituted 1,3,4-oxadiazoles encapsulated in alginate/gelatin particulated systems, Cellulose Chem Technol. 46 (1-2) (2012) 19-25.

[20]. S. Poonam, K.J. Pankaj, Oxadiazoles: A novel class of anti-convulsant agents, Der Chemica Sinica. 1:3 (2010) 118-123.

[21]. V.S. Ramya, M.H. Kallappa, S.K. Rangappa, H.H. Mallinath, Derivatives of benzimidazole pharmacophore: Synthesis, anticonvulsant, antidiabetic and DNA cleavage studies, European Journal of Medicinal Chemistry. 45 (2010) 1753-1759.

[22]. D.S. Musmade, S.R. Pattan, S.Y. Manjunath, Oxadiazole a nucleus with versatile biological behavior, International Journal of Pharmaceutical Chemistry. 5:1 (2015) 11-20.

[23]. S.O. Cledualdo, F.L. Bruno, M. B-F. José, G.F.L. Jorge, FA-F. Petrônio, Synthetic Approaches and Pharmacological Activity of 1,3,4-Oxadiazoles: A Review of the Literature from 2000-2012, Molecules. 17:9 (2012) 10192-10231.

[24]. S. Rakesh, C. Anuja, Various approaches for synthesis of 1,3,4-oxadiazole derivatives and their pharmacological activity, World Journal of Pharmacy and Pharmaceutical Sciences. 3:10 (2014) 1474-1505,

[25]. Z. Chang, C. Fang, Z. Guang-ming, J. Min, Y. Zhong-zhu, Y. Zhi-gang, Z. Meng-ying, S. Liu-qing, Quaternary ammonium compounds (QACs): A review on occurrence, fate and toxicity in the environment, Science of the Total Environment. 518-519 (2015) 352-62.

[26]. S. Buffet-Bataillon, B. Branger, M. Cormier, M. Bonnaure-Mallet, A. Jolivet-Gougeon, Effect of higher minimum inhibitory concentrations of quaternary ammonium compounds in clinical E. coli isolates on antibiotic susceptibilities and clinical outcomes, Journal of Hospital Infection., 79 (2011) 141-146.

[27]. T. Ulas, G. P. Spyros, Quaternary ammonium disinfectants: Microbial adaptation,Degradation and ecology, Current Opinion in Biotechnology. 33 (2015) 296-304.

[28]. C.J.I. Denyer, W.H. Geoff, P. Stephen, Action of Disinfectant Quaternary Ammonium Compounds against Staphylococcus aureus, Antimicrob Agents Chemother. 51:1 (2007) 296306.

[29]. W.G. Jian, Z. Xing, Z. Hua, J.F. Li, D.C. Ying, Synthesis of novel quaternary ammonium surfactants containing adamantine, Chinese Chemical Letters. 23 (2012) 653-656.

[30]. T. Evren, T. Cihat , K. S. çio g, Nami, Y. Tsuyoshi, Termite resistance of solid wood and plywood treated with quaternary ammonia compounds and common fire retardants, International Biodeterioration \& Biodegradation. 65 (2011) 565-568.

[31]. A. Vildan, T. Hüseyin, E. Erçin, Synthesis and antimicrobial activities of some pyridinium salts, J Fac Pharm, Ankara. 35:3 (2006) 177-188.

[32]. T. Maximilian, P. Gabriele, O. Knut, H. Ulrike, Quaternary Ammonium Salts and Their Antimicrobial Potential: Targets or Nonspecific Interactions?, Chem Med Chem. 7 (2012) 2231.

[33]. M. C-R Ana, D. M. C Letícia, Cationic Antimicrobial Polymers and Their Assemblies, Int. J. Mol. Sci. 14 (2013) 9906-9946.

[34]. S. Mandeep, G. Anita, S. Anjali, K. Vineet, Synthesis of quarternary ammonium salts with dithiocarbamate moiety and their antifungal activities against Helminthosporium oryzae, $J$ Chem Sci. 125:3 (2013) 567-573.

[35]. N. Hamini-Kadar, F. Hamdane, R. Boutoutaou, M. Kihal, J. E. Henni, Antifungal activity of clove (syzygium aromaticum) essential oil against phytopathogenic fungi of tomato (solanum lycopersicum) in Algeria, Journal of Experimental Biology and Agricultural Sciences. 2:5 (2014) 448-454.

[36]. B.S Furniss, A.J Hannford, P.W.G Smith, A.R Tatchell, Vogel's Text Book of Practical Organic Chemistry, Pearson Education India, 1989. 